Archives of Agriculture and Environmental Science

\title{
Economics of potato (Solanum tuberosum L.) production in terai region of Nepal
}

\author{
Sanjiv Subedi ${ }^{1 *}$ D , Yuga Nath Ghimire ${ }^{1}$, Sudip Gautam ${ }^{1}$, Hema Kumari Poudel ${ }^{1}$ and Jiban \\ Shrestha ${ }^{2}$ \\ ${ }^{1}$ Socioeconomics and Agricultural Research Policy Division, Nepal Agricultural Research Council, Khumaltar, Lalitpur, NEPAL \\ ${ }^{2}$ Nepal Agricultural Research Council, Agriculture Botany Division, Khumaltar, Lalitpur, NEPAL \\ "Corresponding author's E-mail: sanjiv.subedi@gmail.com
}

\section{ARTICLE HISTORY}

Received: 06 February 2019

Revised received: 15 February 2019

Accepted: 17 February 2019

\section{Keywords}

Benefit cost ratio

Descriptive statistics

Indexing

Potato production

\begin{abstract}
Potato is an important cash crop of Nepal. Research was conducted from January to May, 2018 in Jhapa, Bara and Kailali districts for economic assessment of potato production in terai region of Nepal. Pre-tested interview schedule was used to collect the primary information; moreover, one Focal Group Discussion and two Key Informant Interviews were performed. Furthermore, relevant literatures were reviewed for secondary information. The simple random method of sampling was used within the clusters that were identified in consultation with District Agriculture Development Office, Potato Superzone Office and agricultural officials of the local government. Altogether, 165 samples, 55 samples from each of the three districts were taken for the purpose of the study. The Statistical Packages for Social Sciences (SPSS) and Microsoft excel software were used for data analysis. The majority of the respondents (52.7\%) prioritized the source-Own home production/ Neighbors/ Friends as the first major source for seed followed by Cooperatives/ Farmer's group (20\%). More than one third of the farmers (35.2\%) sold their produce at Home/Local market/Haatbazar followed by Wholesalers/ Distant market (34.5\%). The average gross margin per Kattha from potato production was found NRs. 6604.4 and benefit cost ratio was 2.13. The indexing identifiedlack of availability of improved quality seed $(I=0.79)$ as the most important problem followed by incidence of disease and insect/pest $(I=0.71)$ for potato production. The provision of technical knowledge to control diseases as well as proper allocation of improved quality seed would help to increase profitability and productivity of potato.
\end{abstract}

(C)2019 Agriculture and Environmental Science Academy

Citation of this article: Subedi, S., Ghimire, Y.N., Gautam, S., Poudel, H.K. and Shrestha, J. (2019). Economics of potato (Solanum tuberosum L.) production in terai region of Nepal. Archives of Agriculture and Environmental Science, 4(1): 57-62, https://dx.doi.org/10.26832/24566632.2019.040109

\section{INTRODUCTION}

Potato (Solanum tuberosum L.) is one of the important food crops which is cultivated in $1,85,879$ ha in Nepal. It is the second most important cash crop of Nepal after oilseed (2, 07,978 ha.), in terms of area. Moreover, it is the fourth most important staple crop after rice, maize, and wheat in Nepal (MOAD, 2018). The production and productivity of potato in Nepal in the year 2016/17 has been reported to be $2591686 \mathrm{Mt}$. and $13943 \mathrm{~kg} /$ ha, respectively. In addition, the production of potato in the eastern, central and far-western terai were found to be highest in the districts- Jhapa (221843 Mt.), Bara (126810 Mt.) and Kailali (75100 Mt.) respectively (MOAD, 2018). The different varieties of potato found to be grown in Nepal are: Cardinal, TPS, Khumal Rato, Arun Gold, Kanpure, Lal Gulab, C40, Kufri Sinduri, Desiree and so on (AICC, 2018). Most of these improved varieties are high yielding than local varieties; adoption of improved varieties can greatly enhance national potato production.

Nepal is one of the top twenty countries where potato contributes substantially for the human diet. Potato consists of high starch $(16.1 / 100 \mathrm{~g})$, protein $(2.1 / 100 \mathrm{~g})$, vitamin C (17.1 mg/100 g), potassium (443 mg/100 g) and essential amino 
acids (DADO, 2015). Therefore, potato could be a good option to improve health and nutrition factor of rural population. Also, it is considered more productive than major cereals and has high economic value than cereals (Ghimire and Dhakal, 2014). Potatoes are used as subsidiary food as part of vegetables in Terai region, whereas as staple food in Hill and Mountain regions. The demand of potato in the form of chips, fries and mashed potatoes has widened its scope which helps to uplift the economic condition of smallholder farmers.

Potato is one of the important crops to address food insecurity in the country. However, the potato production of Nepal is subjected to many research questions- financial viability, cost attributes, seed sources and product selling units, problems associated with the production and so on. The productivity of potato can be increased by the use of scientific technology which helps in assuring food security (Manjunah et al., 2013). Unavailability of quality seeds, lack of fertilizers at right time, shortage of labor, poor market, lack of technical knowledge on pest management and topographical barriers are the major problems observed in potato cultivation. This research aims to address these research gaps; agribusiness being crucial lever of rural development and income improvement in Nepal, it is important to conduct empirical research to generate knowledge on economics of agricultural production and its marketing.

Furthermore, this study provides the information on costs and benefits in potato production, identification of major seed sources and produce selling units, and associated problems in production. This research would help the policy makers and researchers in identification of potential area for intervention as well.

\section{METHODOLOGY}

\section{Study area, sample size and data collection technique}

The three districts- Jhapa, Bara and Kailali were selected from eastern, central and far-western terai regions of Nepal respectively, taking account of their highest production in their respective regions (Figure 1). Pre-tested interview schedule was used to collect the primary information; in addition, one Focal Group Discussion and two Key Informant Interviews were performed. Furthermore, various relevant literatures were reviewed for secondary information. The simple random method of sampling was used within the clusters that were identified in consultation with District Agriculture Development Office, Potato Superzone Office and agricultural officials of the local government. Altogether, 165 samples, 55 samples from each of the three districts were taken for the purpose of the study, omitting the outliers and incomplete responses.

\section{Methods and techniques of data analysis}

Data entry and analysis was done by using computer software packages like the Statistical Package for Social Science (SPSS) and Microsoft Excel. Simple descriptive statistics such as average, frequency, percentage and qualitative analysisindexing/scaling technique were used for the analysis. The following analyses were performed.

\section{Gross margin}

Gross margin for any enterprise is the difference between the enterprise gross return and the variable cost incurred to that enterprise. The gross margin shows the clear picture whether the variable cost incurred in the production process is covered by the value of the product (Gujrati, 2003).

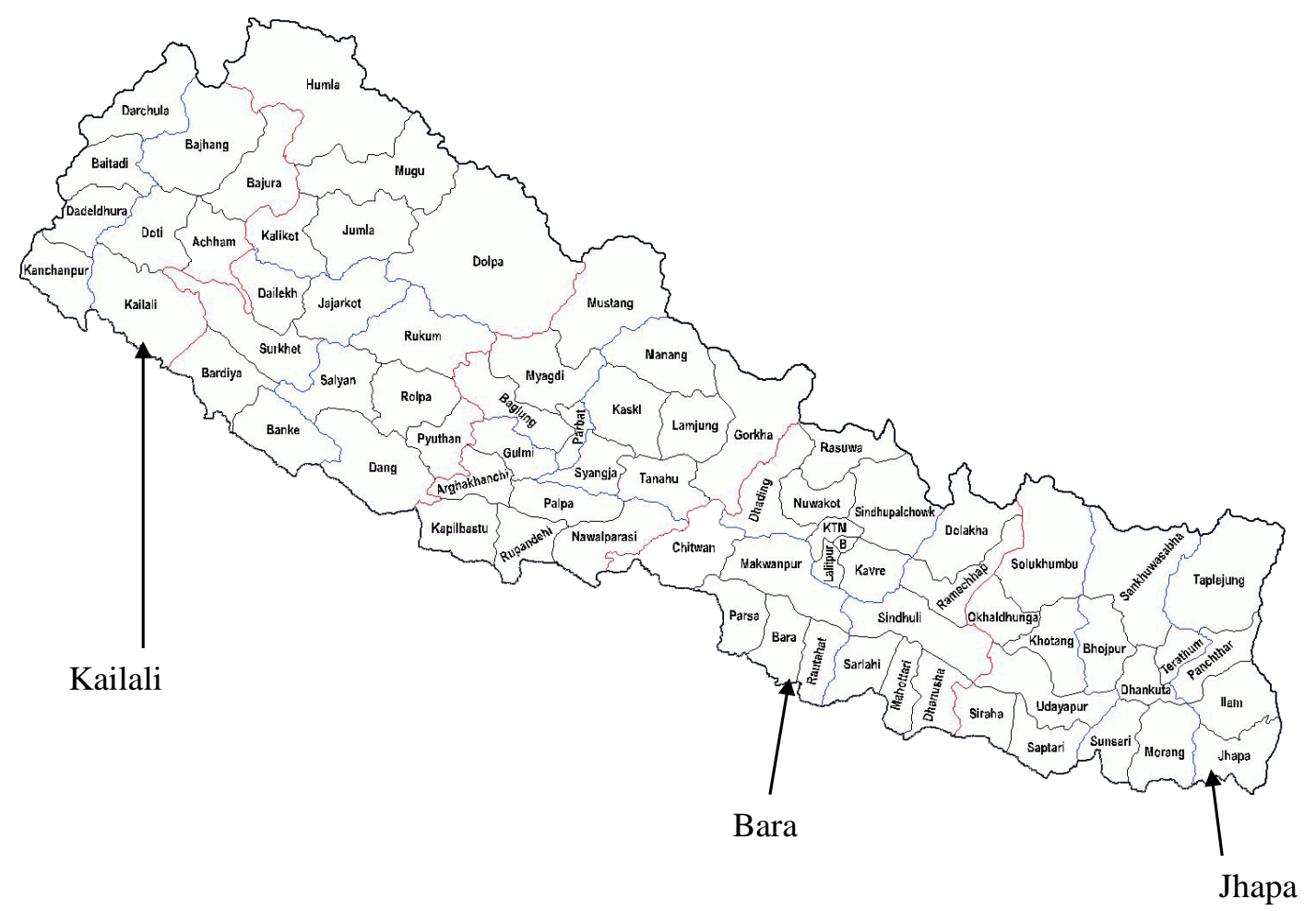


Gross margin $=$ Gross return - Total variable cost

Where, Gross return $=$ Price $\times$ total quantity marketed

Total variable cost $=$ Summation of cost incurred in all the variable items.

\section{Benefit cost analysis}

Benefit cost analysis was done after calculating the total cost and gross return from the potato production. Cost of production was calculated by summing the variable cost items in the production process. For calculating gross return, income from product sale was accounted. Therefore, the benefit cost analysis was carried out by calculating the benefit cost ratio (BCR) using the formula:

$$
\mathrm{BCR}=\frac{\text { Gross return }}{\text { Total cost }}
$$

Timsina (2010); Adhikari (2011) and Amgai et al. (2016) also used the similar formula to calculate the benefit cost ratio for assessing the benefit cost analysis.

Identification of major sources of seed and produce selling units

Simply, the descriptive statistics-frequency and percentage was used to identify and explore the major seed sources and produce selling units.

\section{Problems in production}

Indexing/Scaling technique was applied to construct an index for prioritizing the problems as per farmers' perception using MS-Excel. Scaling techniques provide the direction and extremity attitude of the respondents towards the proposition. Farmer's perception to the different production problems were ranked by using five point scales. Then the priority index was calculated by estimating weight age average mean. The index was computed by using the formula,

Iprob $=\sum$ Si fi $/ N$ where, Iprob = index value for intensity of problem

$\Sigma=$ summation

$\mathrm{Si}=$ scale value at ith intensity/severity

$\mathrm{fi}=$ frequency of the ith severity

$\mathrm{N}=$ total no. of the respondents $=\sum \mathrm{f}$

where, Iprob = index, $0<1<1$

\section{RESULTS AND DISCUSSION}

\section{Cost of potato production}

The total variable cost for potato production in the study area in one kattha land was calculated NRs. 5850. Moreover, the cost of potato production in 1 kattha of land was found to be lowest in Bara (NRs. 4427) followed by Kailali (NRs. 6290) and Jhapa (NRs. 6833). The cost of production is the major factor that influences the profitability of agricultural production. In the study area, seed cost was found to be the first major cost attributing items among all variable items. Human labor followed seed in this respect. Human labour was required for performing different operations such as planting, fertilizer application, pesticides application, irrigation, weeding, harvesting and storage. Seed cost occupied the major portion (33.3\%) of the cost of production followed by the human labour cost (26.3\%), FYM cost (12.3\%), chemical fertilizers cost (7\%), irrigation cost (1.7\%), micronutrient (0.8\%) and pesticides (5.2.\%). Lastly, packaging, storage and transportation cost jointly attributed $3.3 \%$ to total variable cost. In line of these results, Islam et al. (2000) also found the tuber seed cost as 35 to 40 percent of total cost of production. Lack of quality seed in sowing time is one of the major causes for higher seed cost and government subsidy on fertilizer is the major cause for lower fertilizer cost. Also, Kirumba et al. (2004) reported that seed costs contribute a significant $42 \%$ of the total production costs. A study conducted on economics of production of Cucumber in Nawalparasi district revealed that land, human labor, variable and fixed expenses were overused in the production (Sharma, 2010). In contrast to this finding, Mahatha (2012) stated seed, irrigation, plant protection chemicals, potash and Di-ammonium phosphate (DAP) were underused resources in his study. The details of the average cost of potato production are shown in the Table 1.

Table 1. Average cost of potato production per Kattha*.

\begin{tabular}{|c|c|c|c|c|}
\hline Cost attributing items & $\begin{array}{l}\text { Average cost in the } \\
\text { study area }\left({ }^{* *} \text { NRs.) }\right.\end{array}$ & $\begin{array}{l}\text { Average cost in } \\
\text { Jhapa (**NRs.) }\end{array}$ & $\begin{array}{l}\text { Average cost in } \\
\text { Bara (**NRs.) }\end{array}$ & $\begin{array}{l}\text { Average cost in } \\
\text { Kailali (**NRs.) }\end{array}$ \\
\hline Seed & 1950 & 2182.3 & 1470 & 2196.8 \\
\hline Land preparation (Ploughing and leveling) & 586 & 764 & 444.4 & 549 \\
\hline Farmyard manure & 721 & 1137 & 543 & 482.18 \\
\hline Fertilizers (Urea, DAP and MOP) & 414 & 356 & 300.3 & 585.38 \\
\hline $\begin{array}{l}\text { Labour cost (planting, weeding, fertilizer } \\
\text { application, harvesting and storage) }\end{array}$ & 1538 & 1923 & 1096 & 1596.35 \\
\hline Pesticides & 304 & 230.4 & 336.8 & 345.5 \\
\hline Micronutrients & 44 & 44.9 & 25 & 63.6 \\
\hline Irrigation & 99 & 108.4 & 85.7 & 101.55 \\
\hline Packaging, storage and transportation & 194 & 86.8 & 126 & 369.38 \\
\hline Total & 5850 & 6833 & 4427 & 6290 \\
\hline
\end{tabular}

** The rate of $1 \$=1$ USD = 107.57 NRs. (Nepalese Rupees) as of May 15, 2018; ${ }^{*} 1$ hectare $=30$ Kattha. 


\section{Gross return}

The return was obtained from potato sold for seed purpose and food purpose. The average total returns from potato production in one kattha of land in the study area was calculated NRs.12454.4; potato sold for food purpose contributed NRs.6473.4 and that for seed purpose added Rs. 5981. Moreover, the gross return obtained from potato production in 1 kattha of land was highest in the Kailali (NRs. 14400.5) followed by Bara (NRs.13331.5) and Jhapa (NRs. 9632.2). The average selling price of the potato in the study area was estimated NRs. 20.75 per $\mathrm{kg}$. The study revealed that the return from the potato sold for food purpose was highest in Bara (N.Rs. 7326 per kattha) while the return obtained from sale of seed was highest in Kailali (N.Rs. 7476.2 per kattha) (Table 2).

\section{Gross margin}

Gross margin in the study area $=$ Gross returns - Total variable cost

$$
\begin{aligned}
& =\text { NRs. }(12454.4-5850) \\
& =\text { NRs. } 6604.4 \text { per Kattha }
\end{aligned}
$$

Gross margin in Jhapa $=$ Gross returns - Total variable cost

$$
\begin{aligned}
& =\text { NRs. }(9632.2-6833) \\
& =\text { NRs. } 2799.2
\end{aligned}
$$

Gross margin in Bara $=$ Gross returns - Total variable cost

$$
\begin{aligned}
& =\text { NRs. }(13331.5-4427) \\
& =\text { NRs. } 8904.5
\end{aligned}
$$

Gross margin in Kailali $=$ Gross returns - Total variable cost

$$
\begin{aligned}
& =\text { NRs. }(14400.5-6290) \\
& =\text { NRs. } 8110.5
\end{aligned}
$$

The average gross margin from potato production in 1 kattha of land in the study area was calculated N.Rs.6604.4; while the highest gross margin was found to be in Bara (NRs. 8904.5) followed by Kailali (NRs. 8110.5) and Jhapa (NRs. 2799.2). The lowest gross margin in Jhapa was due to having the highest cost of production while the highest gross margin in Bara was due to having the lowest cost of production. Timsina et al. (2011) reported that the gross margin of potato per ropani was N.Rs. 15504.

Gross margin is positive which indicated that the potato production is financially viable. The gross margin shows the clear picture whether the variable cost incurred in the production process is covered by the value of the product. The estimation of gross margin is essential to obtain economic optimization (Gujrati, 2003).

\section{Benefit Cost Ratio}

Benefit Cost Ratio (BCR) ratio in the study area = Gross returns/ Total variable cost

$$
\begin{aligned}
& =\text { NRs. } 12454.4 / \text { NRs. } 5850 \\
& =2.13
\end{aligned}
$$

Benefit Cost Ratio $(B C R)$ ratio in Jhapa $=$ Gross returns $/$ Total variable cost

$=$ NRs.9632.2/ NRs.6833

$=1.41$

Benefit Cost Ratio (BCR) ratio in Bara $=$ Gross returns $/$ Total variable cost

$$
\begin{aligned}
& =\text { NRs.13331.5/ NRs.4427 } \\
& =3.01
\end{aligned}
$$

Benefit Cost Ratio (BCR) ratio in Kailali = Gross returns $/$ Total variable cost

$$
\begin{aligned}
& =\text { NRs. } 14400.5 / \text { NRs. } 6290 \\
& =2.28
\end{aligned}
$$

The BCR in potato production in the study area was calculated 2.13; while the highest BCR was found to be in Bara (3.01) followed by Kailali (2.28) and Jhapa (1.41). As potato is the second most important cash crop and these districts are the major potato growing districts of Nepal in terms of area, production and productivity; the BCR revealed by this research is not surprising. In a like manner, a study conducted on economics of potato production in Taplejung estimated the benefit cost ratio to be 2.9 (Timsina et al., 2011). However, a study carried out in the western mid hill region of Nepal- Baglung district, estimated the benefit cost ratio of potato production to be 1.44 (Bajracharya and Sapkota, 2017).

The BCR in the study area was found to be greater than one which shows the financially feasibility of potato production in terai regions of Nepal. The benefit cost ratio is the ratio of gross returns to cost of cultivation which can also be expressed as return per rupee invested; this implies, if we invest one rupee, we can get the returns of Rs 2.13 (Table 2).

Table 2. Economic indicators of the potato production.

\begin{tabular}{lcccc}
\hline Items & $\begin{array}{c}\text { Study area } \\
\text { Amount (NRs.) }\end{array}$ & $\begin{array}{c}\text { Jhapa } \\
\text { Amount (NRs.) }\end{array}$ & $\begin{array}{c}\text { Bara Amount } \\
\text { (NRs.) }\end{array}$ & $\begin{array}{c}\text { Kailali } \\
\text { Amount (NRs.) }\end{array}$ \\
\hline Total variable cost (NRs./kattha) & 5850 & 6833 & 4427 & 6290 \\
Return from potato sold for food purpose (NRs./Kattha) & 6473.4 & 5170.8 & 7326 & 6924.3 \\
Return from potato sold for seed purpose (NRs./Kattha) & 5981 & 4461.4 & 6005.5 & 7476.2 \\
Gross returns (NRs./Kattha) & 12454.4 & 9632.2 & 13331.5 & 14400.5 \\
Gross margin (NRs./Kattha) & 6604.4 & 2799.2 & 8904.5 & 8110.5 \\
Benefit-cost ratio (BCR) & 2.13 & 1.41 & 3.01 & 2.28 \\
\hline
\end{tabular}

Source: Field survey, 2018 


\section{Seed sources}

The majority of the respondents (52.7\%) prioritized the sourceOwn home production/ Neighbors/ Friends as the first major source for seed followed by Cooperatives/ Farmer's group (20\%), Agrovets (16.4\%), Private seed production farms (4.2\%), Government farms under DOA (3\%), Nepal Agriculture Research Council's farms (2.4\%) and District Agriculture Development Office (1.2\%). Adoption of improved potato is positively related to access of quality improved seeds. It has been reported that the majority of the farmers were using the informal source for seed, which resulted the lower yield (Ghimire, 2005). Shrestha et al. (2016) reported that the production efficiency of vegetable farming could be increased with a greater access to improved seed, agricultural credit and extension services. However, Neupane et al. (2002) and Rogers (2003) stated that farmers' choice on improved varieties is one of the most crucial factors affecting productivity of a crop which is affected by many factors. District Agriculture Development Office has been providing the extension services in the district, which is also one of the sources for potato. It has been stated that the access to extension was positively associated with adoption of improved potato varieties (Paudel and Matsuoka, 2008).

\section{Produce sale}

The potato produced is sold to various units at different prices. The study revealed that more than one third of the farmers (35.2\%) sold their produce at Home/Local market/Haatbazar. This reflects that the farm gate price is nearly equal to the price paid by the consumers, thus higher producer's share on consumer's price. However, the other one third of the farmers (34.5\%) sold their produce to Wholesalers/ Distant market (34.5\%) where they have comparatively lower producer's share. Sapkota et al. (2018) revealed that the farmers who sold their produce directly to consumers received higher share of the consumer's price than those who sold their produce through agents. In addition, more than one quarter of the farmers (27.3\%) responded that they sold their produce to Local level traders and collectors while few farmers (3\%) sold to Cooperatives/ Farmers group/District Agriculture Development Office. A direct relation have been found between market channel choice decisions with quantity sold, access to market information, and distance to the nearest market (Chalwe, 2011; Jeffery et al., 2009).

Table 3. Problems in potato production.

\begin{tabular}{lcc}
\hline Production problems & Index & Rank \\
\hline Lack of availability of improved quality seed & 0.79 & I \\
Incidence of disease and insects/pest & 0.71 & II \\
Lack of proper market & 0.64 & III \\
Lack of proper irrigation facilities & 0.47 & IV \\
Lack of availability of labor & 0.41 & $\mathrm{~V}$ \\
\hline
\end{tabular}

\section{Problems associated with the potato production}

There are various problems associated with the potato production. The major problems in potato production need to be identified prioritized and should be provided the appropriate solutions. Based on the farmers' perception, scaling technique (indexing) was applied to rank the problems. The study revealed that, among the production problems, lack of availability of improved quality seed $(I=0.79)$ was identified as the most important problem followed by incidence of disease and insect/ pest $(I=0.71)$, lack of proper market $(I=0.64)$, lack of proper irrigation facilities $(I=0.47)$, and lack of availability of labor (I=0.41) (Table 3). These are the problems associated with the potato production which are hindering the higher yield. The production could be increased by minimizing or mitigating these problems. It has been reported that the productivity is significantly affected by seed quality, disease and pest infestation and availability of irrigation (Shrestha and Timsina, 2011). Moreover, it has been stated that the low use of quality seeds allied with lack of other inputs (e.g. fertilizer, farm machinery) has decreased the productivity (Gauchan, 2015). Also, it has been revealed that the technical knowledge to control diseases allied with proper allocation of inputs and resources would help to increase profitability and productivity of potato (Bajracharya and Sapkota, 2017).

\section{Conclusion}

The gross margin is positive and benefit cost ratio, greater than one (2.13), which indicates the financial viability of potato production in terai regions of Nepal. However, seed cost has occupied the major portion of cost of production (33.3\%); adoption of improved varieties could decrease the seed rate which minimizes the seed cost. Seeking the response of the majority of the farmers (52.7\%), the seed source- Own home production/ Neighbors/ Friends has been identified as the major source for seed, which indicates towards probability that the larger proportion of the farmers are cultivating either local varieties or low quality seeds. Likewise, regarding sale, more than one third of the farmers (35.2\%) sold their produce at Home/Local market/Haatbazar which shows higher producer's share on consumer's price. Furthermore, lack of availability of improved quality seed was identified as the most important problem followed by incidence of disease and insect/pest, lack of proper market, lack of proper irrigation facilities and lack of availability of labor, associated with the potato production. There is an immense need of proper coordination between agricultural service providers and the farmers; also, strategic plans need to be formulated by the government to address these problems.

\section{ACKNOWLEDGEMENTS}

The authors are thankful to all the respondents of Jhapa, Bara and Kailali districts who provided reliable data to complete this study and officials of DADOs of respective districts for their technical support and warm cooperation. 
Open Access: This is an open access article distributed under the terms of the Creative Commons Attribution 4.0 License, which permits unrestricted use, distribution, and reproduction in any medium, provided the original author(s) if the sources are credited.

\section{REFERENCES}

Adhikari, R.K. (2011). Economics of organic rice production. The Journal of Agriculture and Environment, 12: 97-103, https://doi.org/10.3126/aej.v12i0.7569

AICC. (2018). Krishi Diary. Agriculture Information and Communication Centre. Lalitpur, Nepal. pp. 34.

Amgai, S., Adhikari, B.K. and Kadariya, M. (2016). Economic analysis of cost of production of apple in mustang district of Nepal. The Journal of Agriculture and Environment, 17: 141-147, http://moad.gov.np/public/uploads/2007128766-Journal\% 202016.pdf

Bajracharya, M. and Sapkota, M. (2017). Profitability and productivity of potato (Solanum tuberosum) in Baglung district, Nepal. Agriculture and Food Security, 6, 47, https://doi.org/10.1186/s40066-017-0125-5

Chalwe, S. (2011). Factors Influencing Bean Producers' Choices of Marketing Channels in Zambia. M.Sc thesis. University of Zambia.

DADO. (2015). Annual agriculture development program and statistics book. Baglung: F.Y. 2071/72 Government of Nepal, Ministry of Agricultural Development, District Agriculture Development Office

Gauchan, D. (2015). Research and Support Services in Seed Production and Supply in Nepal. Thematic Paper for Seed Submit, 2015. http:// sqcc.gov.np/ media/ publication/Research_ by _ Devendra. pdf.

Ghimire, B. and Dhakal, S.C. (2014). Production Economics of Sustainable Soil Management based Cauliflower (Brassicae oleracea. L. var. botrytis) in Dhading district of Nepal. American Journal of Agriculture., 2(4):199-205.

Ghimire, N. (2005). Adoption of improved potato technology in Chitwan, Nepal. Economic Journal of Nepal, 28(3):188-199. https://www.nepjol.info/index.php/EJON/article/view/174

Gujrati, D.N. (2003). Basic Econometrics. $4^{\text {th }}$ ed. McGraw- Hill, Singapore. 112-128.

Islam, S.M.F., Anwar, M.M. and Manos, B. (2000). Potato production system in Bangladesh: Resource use, productivity, efficiency and comparative profitability of true potato seed technology over traditional tuber technology. Acta Hortic, 536: 261-268, DOI: 10.17660/ActaHortic.2000.536.30.

Jeffrey, R., Alwang, M. E, Christie and Taylor, D. B. (2009). Effects of Access to Information on Farmer's Market Channel Choice: The Case of Potato in Tiraque Sub-watershed Cochabamba, Bolivia. M.Sc Thesis Agricultural and Applied Economics, Virginia Polytechnic Institute and State University.
Kirumba, W., Kinyae, P. and Muchara, M. (2004). Irish Potato Market. Survey Promotion of Private Sector Development In Agriculture. GTZ/MOA

Mahatha, R.K. (2012). Economics of production and marketing of Potato in Saptari district of Nepal. Master thesis submitted to Institute of Agriculture and Animal Science, Tribhuvan University, Chitwan, Nepal.

Manjunah, K., Dhananjaya Swamy, P.S., Jamkhandi, B.R. and Nadomi, N.N. (2013). Resource use efficiency of Bt cotton and non-Bt cotton in Haveri District of Karnataka. International Journal of Agriculture Food Science \& Technology, 4(3):253-258.

MoAD. (2018). Statistical Information on Nepalese Agriculture 2016/2017. Agribusiness Promotion and Statistic Division. Hariharbhawan, Lalitpur: Ministry of Agricultural Development.

Neupane, R.P., Sharma, K.R. and Thapa, G. B. (2002). Adoption of agroforestry in the hills of Nepal: a logistic regression analysis. Journal of Agricultural Systems, 72: 177-196, RePEc:eee:agisys:v:72:y:2002:i:3:p:177-196

Paudel, P. and Matsuoka, A. (2008). Factors influencing of improved maize varieties in Nepal: A case study of Chitwan district. Australian Journal of Basic and Applied Sciences, 2(4): 823-834, http://ajbasweb.com/old/ajbas/2008/823-834.pdf

Reddy, T. Y. and Reddi, G.H. (2005). Principles of Agronomy. New Delhi, India: Kalyani Publishers.

Rogers, E.M. (2003). Diffusion of Innovations (Fourth Edition). New York: Free Press.

Sapkota, B.K., Dutta, J.P., Chaulagain, T.R. and Subedi, S. (2018). Production and marketing of rice in Naghlebhare Rice Block, Kathmandu: an economic analysis. Nepalese Journal of Agricultural Sciences, 16:138-148.

Sharma, B.P. (2010). Production and marketing of cucumber (Cucumis sativus L.) in Nawalparasi, Nepal: An Economic Analysis. Master thesis submitted to Institute of Agriculture and Animal Science, Tribhuvan University, Rampur, Chitwan, Nepal.

Shrestha, J. and Timsina, K.P. (2011). Agronomic performance and economic analysis of maize (Zea mays L.) under different plant geometry and nitrogen rates in Chitwan, Nepal. Nepalese Journal of Agriculture Science, 9: 5-13.

Shrestha, R.B., Huang, W.C., Gautam, C. and Johnson, T.G. (2016). Efficiency of small scale vegetable farms: policy implications for the rural poverty reduction in Nepal. Agricultural Economics, 62(4):181-195, https://doi.org/10.17221/81/2015-AGRICECON

Timsina, K. (2010). Economics of Ginger Production: A case study of Makawanpur district, Nepal. Journal of the Institute of Agriculture and Animal Sciences, (31 \& 32): 35-41.

Timsina, K.P., Kafe, K. and Sapkota, S. (2011). Economics of potato (Solanum tuberosum L.) production in Taplejung district of Nepal. Agron J Nepal, 2:173-181, https://doi.org/10.3126/ajn.v2i0.7533 